\title{
Molecular Analyses used in Genetic Diversity Studies of Bioactive Plants of Verbenaceae and Lamiaceae: A Review
}

\author{
Fabiany de Andrade Brito, Renata Silva-Mann, Daniela Aparecida de Castro Nizio, Maria de Fátima Arrigoni- \\ Blank and Arie Fitzgerald Blank* \\ Department of Agronomic Engineering, Federal University of Sergipe, Brazil
}

Submission:July 28, 2018; Published: August 27, 2018

"Corresponding author: Arie Fitzgerald Blank, Department of Agronomic Engineering, Federal University of Sergipe, São Cristóvão, Sergipe, Tel: +557931946981; Email: arie.blank@gmail.com

\begin{abstract}
Morphological traits used to be employed to differentiate plant genotypes within breeding programs. With the advancement of biotechnology, biochemical markers and DNA molecular markers have become the primary tools used in the differentiation of individuals, because these markers are not influenced by the environment, as it occurs with morphological traits. Consequently, these new techniques provide faster and more precise results. The isoenzymes and the DNA molecular markers RFLP, RAPD, AFLP, and SSR stand out among the biochemical and molecular markers. Each molecular marker presents advantages and limitations, which increases the applicability to different species and laboratory conditions, presenting more reliable results when used in association. Given the increase in the number of works related to bioactive plant species, this review seeks to present the panorama of the use of biochemical and molecular markers in studies on the genetic diversity involving the families Verbenaceae and Lamiaceae, which encompass a large number of medicinal and aromatic species of economic importance.

Keywords: Medicinal and aromatic plants; Genetic resources; Germplasm; Isoenzymes; Genetic markerss

Abbreviations: RFLP: Restriction Fragment Length Polymorphism (RFLP); RAPD: Random Amplified Polymorphic DNA (RAPD); SCAR: Sequence Characterized Amplified Region; SSR: Simple Sequence Repeats; ISSR: Inter-Simple Sequence Repeat; AFLP: Amplified Fragment Length Polymorphisms; PCR: Polymerase Chain Reaction
\end{abstract}

\section{Introduction}

The identification of plant individuals is usually based on the evaluation of morphological and physiological traits, denominated descriptors [1]. These descriptors are usually influenced by abiotic factors, hindering the identification of sufficient characteristics to discriminate genotypically distinct individuals [2].

Biochemical and molecular markers, which are methodologically more specific, have been used in studies on human beings and can also be applied to forensic genetics for providing high-accuracy information [3]. The automation of molecular techniques, provided by the development of the methodology of in vitro amplification of the genetic material by polymerase chain reaction (PCR), led to molecular markers related to the genomic DNA. These markers allow the identification of polymorphism from the amplification of DNA sequences with different sizes, depending on the technique employed. Therefore, these tools provide more efficient discrimination, mainly between morphologically identical but genetically different individuals.

Molecular markers can be defined as tools that utilize molecules present in an organism to detect genetic variations. Among these molecules, markers based on variations at the DNA level present greater polymorphism between morphologically-related individuals [4]. There are several types of molecular markers, each one with its advantages and restrictions. They are indicated for specific cases, always considering the available infrastructure. Among the DNA markers available, the Restriction Fragment Length Polymorphism (RFLP), Random Amplified Polymorphic DNA (RAPD), Sequence Characterized Amplified Region (SCAR), Simple Sequence Repeats (SSR), Inter-Simple Sequence Repeat (ISSR), and Amplified Fragment Length Polymorphisms (AFLP) are the most frequently used.

The association of molecular markers with other types of genetic markers is useful for allowing the characterization of various biological materials, generating a potential tool for the characterization of plant germplasm. The families Verbenaceae and Lamiaceae, which hold a large number of species of economic and medicinal importance, can be characterized by markers. These families are made up of bioactive species with several biological properties and are used both in folk medicine and in the drug, food, perfume, and cosmetic industries [5]. Much of this bioactivity is related to the presence of secondary metabolites, such as the essential oils. Essential oils are constituted by a variety of compounds, mostly mono and sesquiterpenes. Biotic and abiotic factors can influence their composition. These metabolites can be 
used to distinguish individuals belonging to the same botanical family due to the ability of a given group to synthesize a particular set of substances absent in another genus. However, they are not sufficient to genetically differentiate individuals with the same chemical profile within the same species. Morphologically-similar plants with the same chemical profile may not present the same genotypic constitution. Thus, the essential oils can assist studies on the genetic diversity of populations of the same species. Nevertheless, these metabolites are the result of genetic and environmental factors and/or the interaction between them. In this sense, molecular markers are an essential tool to complement studies related to these families since they allow the direct assessment of variations in the level of nitrogenous bases in plant genomes, providing more precise information.

\section{Family Verbenaceae}

The family Verbenaceae J.St.-Hil. comprises approximately 36 genera and 1000 species. It has a pantropical distribution, occurring mostly in in tropical and temperate zones [6-7]. Brazil holds approximately 16 genera and 250 species [8]. The presence of glandular trichomes, which produce essential oils of great medicinal importance, is a marked characteristic of this family. Some genera have stood out owing to their medicinal uses, such as Lantana, Stachytarpheta, and Lippia [9-10].

The use of chemical markers has been reported for the genus Lantana in an analysis of 15 species, revealing $(E)$-caryophyllene as the major compound and phellandrene, cubebene, and elixene as minor compounds. However, (E)-caryophyllene was not detected as the major compound in the genus Lippia. Instead, studies suggested that species belonging to the genus Lippia contain limonene, citral, carvacrol, $\beta$-myrcene, camphor, and thymol as their main chemical markers. In addition to essential oils, other secondary metabolites can be used to distinguish genera or families. A taxonomic study of four genera of the family Verbenaceae (Lippia, Lantana, Aloysia, and Phyla) proposed the presence of iridoid glycosides as a taxonomic descriptor for this family [11-12].

The genus Lippia contains approximately 200 taxa and 160 species of herbs, shrubs, and small trees, many of which are rich in essential oils [10,13-14]. These plants are widely distributed in Tropical Africa, Mexico, Central America, Paraguay, Argentina, and Brazil, accounting for approximately $70-75 \%$ of the species. Many of the Brazilian species are endemic and are concentrated in the Serra do Espinhaço, Minas Gerais, and Goiás, where they grow between rocks. Due to their characteristics and to anthropic activities in these regions, such as mining, these endemic species are endangered $[7,10,15]$. Despite being spread all over the Brazilian territory, reports on the genus Lippia are concentrated in species popularly used in the northeastern region of the country. Some of them have been included in the official programs of primary health care [16], with emphasis on the species Lippia alba (Mill.) N.E. Br. and Lippia sidoides Cham. Moreover, the latter occurs nation-wide.

\section{Family Lamiaceae}

The family Lamiaceae is the largest of the order Lamiales, an order that includes between 20 and 30 families. Studies on the morphology, chemistry, and molecular phylogeny have changed the classification of this family, resulting in the addition of a large number of genera that had originally been classified in the family Verbenaceae. As a result, the family has about 240 genera and 7,200 species, occurring in tropical and temperate areas around the world. Currently, 32 genera and approximately 496 species are native to Brazil, although this number is constantly changing due to new discoveries. Seven subfamilies have been recognized, five of which occur in South America. The main genera of the family Lamiaceae native to Brazil include Vitex, Aegiphila, Amasonia, Rotheca, Clerodendrum, Volkameria, Scutellaria, Leonurus, Leucas, Leonotis, Ocimum, Marsypianthes, Hypenia, Eriope, Hyptidendron, Hyptis, and Heltodon [17,18,19].

This family consists mainly aromatic herbs and shrubs that contain essential oil secretory glands. The plants present quadrangular stems and opposite leaves, and the inflorescences have raceme aspect [20].

This family is one of the most diverse and generalized regarding ethnomedicine, and its medicinal value is due to the concentration of volatile oils, which are important for the pharmaceutical, perfumery, cosmetics, pesticides, and flavoring industries $[4,21]$. Medicinal plants have socio-cultural, spiritual, and medicinal value in rural and tribal lives of developing countries [22]. People from all over the world use between 50,000 and 80,000 plants for medicinal purposes [23].

\section{Isoenzymatic Molecular Markers}

Isoenzymatic markers were the first ones to be used in molecular differentiation between individuals. Despite their pioneering nature, these markers are usually employed to obtain information related to genetic variability levels in natural populations [24].

From the information contained in the genomic DNA, with the translation process, reading of the sequence of messenger RNA (mRNA) for protein synthesis occurs, using polymerization in amino acids peptide bonds. Among the proteins formed, those with catalytic function are denominated enzymes, being responsible for catalyzing reactions in an organism in the presence of a specific substrate. Some of these enzymes may have the same affinity for a given substrate but different molecular weights, i.e., they are molecularly distinct enzymes, denominated isoenzymes. Despite having the same catalytic functions, they can be biochemically differentiated [25]. Thus, the electrophoresis analysis allows to visualize and genetically discriminate the isoenzymatic differentiation between individuals, species, and populations.

The isoenzymatic discrimination and its applications have expanded in plant genetics research, and the investigation of the patterns of genetic variability is one of its main characteristics $[24,26]$. Wild barley [27] and wheat [28] were some of the first 
studies related to genetic discrimination by isoenzymes. Regarding bioactive plants, two populations of Ocimum nudicaule were the first ones to be analyzed by isoenzymes [29].

The identification of variability levels enables the evaluation of the genetic structure in natural populations, which increases the efficiency of plant breeding programs and helps the study on the conservation of native genetic resources [30]. For instance, when assessing the genetic diversity of the endangered species Dracocephalum austriacum, high genetic diversity was identified within populations, which allowed selecting populations that were suitable for genetic diversity conservation [31] and genotypes that could work as parents in future breeding programs.

The diversity and genetic structure of 25 natural populations of Thymus capitatus, an ornamental plant of the Mediterranean region, were analyzed by eight isoenzymes [32]. Eleven polymorphic loci were detected, and many of them showed rare alleles. These results corroborate studies on isoenzymatic diversity using other species of the family Lamiaceae [33-34]. Differentiation and genetic similarities between populations indicate they have recently been isolated by anthropogenic pressure. However, based on the authors' estimates, most populations showed high variation, suggesting that the populations constitute suitable germplasm for conservation and use in breeding programs.

Seven natural populations of Teucrium polium were assessed using isoenzymes and RAPD regarding their diversity and genetic structure. The genetic profile within the population had similar results for both markers. Forty-six electrophoretic bands were detected by seven isoenzymes, and 144 loci were amplified by eight RAPD primers [35], proving to be promising tools for genotypes characterization.

Despite their efficiency, isoenzymatic markers are limited by the reduced coverage. Only a small number of loci can be identified by this method. In addition, these enzymes can change depending on the environmental influence, the plant development stage, and the tissue analyzed [5].

\section{DNA Molecular Markers}

DNA molecular markers emerged aiming at sampling different regions of the genome from the structural and molecular knowledge of the deoxyribonucleic acid.

\section{RFLP (Restriction fragment length polymorphism)}

At molecular level, the main difference between two individuals is detected from the genetic constitution of each organism. This difference is the main characteristic that generates polymorphisms. From this principle, the Restriction Fragment Length Polymorphism (RFLP) was developed [36], being one of the first molecular markers based on the DNA molecule. The detection technique of the RFLPs markers uses restriction enzymes, responsible for cleaving the genomic DNA at distinct but specific points, allowing the formation of several fragments, whose sizes will correspond to the target region of the enzyme. The product generated is then separated by electrophoresis, visualized by radioactivity, or stained with fluorochromes. The polymorphism visualized at the end is generated from mutations and alterations in restriction sites corresponding to the enzyme used.

The RFLP markers are easily reproducible. They have high polymorphism and can differentiate homozygote from heterozygote individuals. However, the main disadvantage is the lengthy development time and the large amount of high-quality genomic DNA [25].

Different species have been the target of studies with RFLP, which aim to characterize the existing variability. Maize was the first plant to be studied using RFLP markers $[37,38]$.

Phylogenetic studies carried out in mangroves using RFLP molecular markers revealed data that favored the classification of Avicennia spp., Verbenaceae, into another family, Avicenniaceae [39]. Due to the toxicity present in Salvia divinorum, which can provoke psychotropic hallucinations, the combination of analytical chemistry and RFLP molecular methods identified samples of $S$. divinorum, assisting the forensic and toxicological sciences [40]. Moreover, when studying the applicability of RFLP markers to Salvia genotyping, researchers correlated molecular results with levels of essential oil production. However, their results indicate the need for further studies on the genetic variations of Salvia [41].

The emergence of plant hybrids is a phenomenon that can naturally occur. Nevertheless, it may affect the performance and potentiate the extinction of rare species. RFLP markers and morphological analyses were fundamental to distinguish endangered taxa and their hybrids with the exotic plant Lantana strigocamara.

Lately, the isoenzymatic molecular markers and RFLP have been poorly used. Conversely, depending on the species, they may still be useful [42]. Despite their great collaboration at the beginning of genetic diversity studies of several plant species, they were replaced by more modern techniques, which have greater reproducibility and specificity in accessing species genomes.

\section{SSR (Simple Sequence Repeats)}

The SSR microsatellite markers were first described in plants by Condit \& Hubbell [43], who detected the repeats (AC)n and (AG)n. The application of microsatellites as PCR primers was first described by Lieckfeldt et al. [44] and Meyer et al. [45]. The genome of eukaryotic species is densely populated by different classes, with repeated sequences and little complexity. The terms Simple Sequence Repeats (SSR) or Short Tandem Repeats (STR) were later replaced by Microsatellite Markers [46-47]. Morgante \& Olivieri [48] clarified that microsatellites occurred in 34 plant species and that AT repeats were the most commonly detected class of nucleotide microsatellites. They also found that the microsatellite markers were more frequent in the plant species than in invertebrates and fungi and less frequent in vertebrates.

Microsatellite markers are formed by sets of tandem repeats (one after another), with length from two to six nucleotides, and occur between the most polymorphic loci of the genomes $[49,50]$. 
Regions containing SSR are individually amplified by PCR using a pair of specific primers (from 20 to 30 bases), which complement the sequences flanking the microsatellite. In view of codominance and multiallelism, microsatellites have the highest genetic information content, which, together with the need for a small amount of DNA, makes them the ideal genetic markers for genetic mapping, with higher efficiency for studies on diversity, varieties protection, and assisted selection [51-54].

To use SSR markers, specific primers for the target species must be developed by constructing genomic libraries, selecting and sequencing positive clones, and designing the primers. Subsequently, amplification with PCR, agarose gel electrophoresis, or polyacrylamide is performed, and then the polymorphism is visualized by staining with silver or fluorescent (polyacrylamide) or with ethidium bromide solution (under ultraviolet light) (agarose). One of the disadvantages of these markers is the high cost for the development of primers $[55,56]$. However, primers that have been developed for a determined species can be used in another species of the same genus due to microsatellite sites maintained between species [25]. These primers are denominated heterologous primers. Microsatellites are classified according to the composition of the repeated sequences, as follows: perfect repeats, without any interruption, such as 12 GTGTGTGTGTGTGT; imperfect repeats, interrupted by bases that do not match the motif, such as GTGTGTGTaGTGTGTT; and compound repeats, at which two or more microsatellite repeats (classes) are adjacent to one another, such as GTGTGTGTGTGTCACACACACACA) [5].

A comparative study on the breeding system and genetic structures of two species of the genus Clerodendrum, using SSR markers, resulted in the genetic information and knowledge about the taxa, the degree of inbreeding depression, pollen/seed dispersal distance, and pollen genetic diversity on pollinators. In a study on Verbenoxylum reitzii (Verbenaceae), an endemic tree of the Brazilian Atlantic Forest, which investigated its usefulness in population genetic studies, SSR markers revealed high polymorphism, acting as a powerful tool for genetic and phylogeographic studies of populations. The marker was effective, providing genetic information for the development of conservation strategies for the species [57-58].

In a study with Pogostemon cablin, microsatellite primers were developed to characterize the Active Germplasm Bank of the Federal University of Sergipe. Twelve microsatellites were developed, out of which six were polymorphic. The genetic diversity was efficiently identified, providing new information for research on the species, which will subsidize conservation strategies and open paths to other studies [59].

Previously developed microsatellite markers and nine others that were later isolated from Salvia officinalis L., an endemic species occurring in only two locations in the Balkan Peninsula, were evaluated. Of the 30 markers tested in the natural population, 15 were successfully amplified, allowing the comparison of the genetic variation between plants. This study also shows the lesser genetic variation of rare species [60].
Genetic variability analysis was carried out between populations of Minthostachys verticillata collected in Central and Northwestern Argentina. Ninety-three plants from nine sites were analyzed, and results revealed that variability was higher between than within populations. The cluster analysis identified three clusters. The genetic variability observed in the study was higher than that represented in previous phytochemical reports, although the plants are found in the large distribution area, with significant anthropogenic action. The Mantel test demonstrated a positive and significant correlation between genetic and geographic distance. Applying SSR markers to native species can be useful for the analysis of natural populations, complementing the chemical analysis and developing markers associated with compounds in native species [61].

A study on endangered populations of Origanum compactum revealed that the Gibraltar strait could have been a plant migration route between southern Spain and northern Morocco. Their isolation may have caused the high population differentiation (Fst $=0.22)$ and low gene flow $(\mathrm{Nm}=0.88)$. These results highlight the importance of developing appropriate conservation strategies for these species, such as partially restoring the gene flow in fragmented and isolated populations that could be quickly extinguished. This technique will be useful for future breeding programs [62].

The genetic diversity and population structure of 18 populations of Rosmarinus officinalis, a Mediterranean shrub plant, was analyzed using SSR markers. The authors proposed that the life history and reproductive characteristics contribute mainly to explain the high levels of genetic diversity and the weak population structure. Eleven microsatellite loci were polymorphic in all the 18 populations of $R$. officinalis, totaling 231 different alleles [63].

With the development of a genomic library, nine microsatellite primers were obtained for Lippia alba and used in the characterization of the germplasm of the University of São Paulo. Six of them produced polymorphisms, dividing the germplasm into two clusters. The data assists the characterization of germplasm banks, L. alba breeding programs, and other studies on genetic diversity and classification of species of the genus Lippia [64].

SSR markers were also developed for Phyla scaberrima to determine the genetic variability and population structure patterns of the species, totaling 11 primers. Fifty-six alleles were detected in 48 individuals belonging to three different populations. The mean number of alleles per locus was 5.09, while the polymorphic information content ranged from 0.000 to 0.587 . The 11 pairs of primers were also tested for amplification in six species of the genus Lippia. The transferability rate varied from four loci in Lippia florida and L. rotundifolia to six loci in $L$. corymbosa and L. microcephala. The 11 primers set proved to be valuable tools for population genetic studies in $P$. scaberrima and in species of the genus Lippia in which primers transferability was effective [65]. 


\section{RAPD (Random Amplified Polymorphic DNA)}

The Random Amplified Polymorphic DNA was one of the first markers developed after the enhancement of PCR. The RAPD technique consists of the use of primers with arbitrary sequences, useful mainly in studies with species that have not been genetically described. It is a rapid technique and has a high potential to detect polymorphism even with small amounts of available genomic DNA [66]. In this reaction, the primer pairs with the genomic DNA at two different sites and complements the DNA template. If these primers are located between an amplifiable range-from $300 \mathrm{bp}$ to $2.5 \mathrm{~kb}$-a DNA product is formed by thermocyclic amplification. Polymorphisms are perceived by the presence or absence of primer binding sites and can be detected by agarose gel resolution [67].

Initially, RAPD was used by Williams et al. [68] to construct genetic maps for several species. Subsequently, according to the need, RAPD could be adapted to various situations, such as gene coding and identification of resistant genes in plants [69-71]. The RAPD technique became popular for its simplicity, efficiency, and easy performance. Moreover, they do not require information on the previous sequence [72].

The Random Amplified Polymorphic DNA methodology stands out due to its low cost, practicality, demand for small amounts of DNA, and applicability to species whose genetic material is unknown or presents few isoenzymatic polymorphism. The little knowledge about the genetics of the study species is related to the use of random primers. These primers amplify several regions of the genome without prior knowledge of the DNA sequence [73]. Unlike the isoenzymatic markers, whose applicability is related to the transcribed regions, RAPD markers have a greater genome range, amplifying both coding and non-coding regions [74].

The primary limitations of the RAPD technique are the variable reproducibility of results and the limited genetic information per locus due to its dominant behavior. In other words, the technique does not distinguish heterozygote from homozygote genotypes $[25,68]$.

The RAPD technique was used in a study on the genetic similarity and for the construction of fingerprints of a group of Mesona chinensis. Eighteen cultivars and a hybrid were assessed based on RAPD markers. The study resulted in three primers that could completely distinguish the 19 samples and the similarity index. The subsequent clustering analysis divided the cultivars into five clusters. Moreover, the results of the markers revealed correlations between regional distributions and parental sources. These data provide useful subsidies for the classification, identification, and cultivation of this species [75].

The genetic variability of 11 populations, corresponding to nine species of the genus Lippia (L. corymbosa, L. diamantinensis, L. filifolia, L. florida, L. hermannioides, L. lupulina, L. rotundifolia, L. rosella, and L. sidoides), found in the Brazilian southeast, was assessed by RAPD molecular markers. The analysis was performed using 18 primers, generating 490 fragments, of which only one presented monomorphic traits for the individuals. With the data generated in the analysis, a dendrogram (UPGMA) was constructed with two major clusters. In addition, they observed that the mean interspecific genetic distances were similar for all species and higher than intraspecific genetic distances. This result confirms the efficiency of the use of RAPD markers in the analysis of genetic diversity for Lippia species and their contribution to conservation and taxonomic implications [15].

In the Anand region, in Gujarat, India, an efficient protocol for plant regeneration via organogenesis was developed, which analyzed the genetic homogeneity of clonal lines established by random amplified polymorphic DNA (RAPD) and ISSR of Vitex trifolia species (family Lamiaceae). After the successful plant regeneration from calli derived from stem, leaf, and petioles explants, the genetic analysis was performed using the marker. A total of 40 seedlings were analyzed using 60 RAPD primers and 27 ISSR primers. Of the 60 RAPD primers, 20 were selected, generating 125 countable bands. Meanwhile, for the 27 ISSR primers, 12 were selected, generating 49 bands. The authors concluded that the use of different explants (stem, leaf, and petiole) is advantageous for mass propagation and genetic transformation, confirming the efficiency of the RAPD and ISSR techniques to evaluate the nature of regenerated clones of $V$. trifolia [76].

To understand the genetic variation of three chemotypes of Lippia alba Mill. (Verbenaceae), the cytogenetic analysis of pollen viability and the nuclear DNA content were evaluated by the RAPD technique. The authors observed different ploidy levels and mixoploid individuals. Moreover, the flow cytometric analysis revealed an increase in the nuclear DNA content that was not directly proportional to the ploidy level variation. Fortyseven random primers were used, of which ten polymorphic primers were selected. RAPD markers showed that most of the genetic variation might be a consequence of mixoploidy. Results demonstrated that chromosomal analysis, quantification of estimated nuclear DNA, and RAPD markers are excellent tools to detect genetic variation between L. alba chemotypes [77].

Another study applied RAPD molecular markers and compared ITS sequences to estimate the genetic variability of Verbena officinalis (Verbenaceae), aiming to generate a precise authentication method. Results showed that both techniques allowed the differentiation of $V$. officinalis from the rest of the genus, despite the existing intra-specific variation [78].

Nine Ocimum genotypes naturally cultivated in the Dakshin Dinajpur district, India, were genetically described by RAPD markers, which clearly showed that Ocimum africanum and Ocimum basilicum are different species. The authors also pointed out that the morpho-chemical and molecular study can be used as complementary methods in the description of the genotype diversity within the genus Ocimum for its correct identification and taxonomic classification [79]. 


\section{ISSR (Inter-simple sequence repeat)}

The Inter-Simple Sequence Repeat markers (ISSR) were first introduced by Zietkiewicz et al. [80], where the 3' terminus of the DNA is anchored, and the primers are used to amplify the interSSR sequences or SSR flanking sequences. These markers were employed to conduct genetic diversity studies [81].

The method employed by the ISSR markers is based on the microsatellites. They are dominant and do not differ heterozygote from the homozygote individuals. However, they analyze multiple loci in a single reaction. Their primers may be anchored at 5'or 3 ' termini with one to four degenerate bases, based on DNA amplification by the PCR technique. This technique is simple and efficient due to its high reproducibility and repeatability, generating high polymorphism degree. Its use has become increasingly common. When using primers anchored at the 5' terminus, the amplification products include the microsatellite sequence and its size variations in the genome, providing a higher polymorphism degree and a larger number of bands [82]. No previous knowledge of the genome is required to use this technique. Despite being dominant markers, they can be used to assess multiple loci in a single reaction [83,84].

The limitation of this marker is related to the fact that, for being dominant, the presence of the band can represent the dominant homozygote or the heterozygote individual, assuming that the absence of the band is the recessive homozygote. However, the presence or absence of the band may be related to the occurrence of insertions or deletions in the primer binding site [80,85]. ISSR primers are more robust than RAPD primers for they have a larger anchoring surface and higher annealing temperatures, increasing products reproducibility [86].

The chemical and molecular characterization of fifteen species of the genus Lantana (Verbenaceae) will assist future studies on the genetic and chemical evaluation of this species and other genera belonging to the Verbenaceae family, which should include a larger number of species, aiming at a more complete study on the chemical, genetic, and taxonomic diversity of these plants [87].

A study with twenty-seven accessions of Lippia alba Mill. from Rio Grande do Sul, Brazil, used ISSR and RAPD markers to evaluate the genetic variability and the relation between accessions. The genetic variability was high when compared with that of other plant species. The UPGMA method showed a low relation between accessions, and no clusters were formed between accessions belonging to the same chemotype. The two markers were efficient to evaluate the genetic diversity in $L . a l b a$ and may contribute to the conservation and breeding of the species [88].

Savory herb (Lamiaceae) is one of the most relevant medicinal plants of Iran, which is one of the most significant repositories of Savory germplasm, accounting for about 16 species of the genus Satureia. Ten different populations of three species (Satureia rechingeri, S. khuzistanica, and S. spicigera) were evaluated for their genetic diversity using ISSR. Three primers that produced clear and reproducible fragments were selected, generating 19 bands. Results of this study revealed that ISSR markers could be used efficiently in the genetic differentiation of the species [89].

A study on Mentha cervina evaluated the morphological, phytochemical, and genetic differences in 12 populations, aiming to obtain the diversity level between them. The relatively low genetic diversity detected in the populations analyzed indicates that the maintenance of their evolutionary potential is threatened if population sizes are maintained and if the habitats are not protected. The amplification of the 121 individuals by ISSR generated 175 bands, corresponding to a mean of 82.4 fragments per individual. Of these bands, 171 were polymorphic $(97.7 \%)$. The genetic diversity of M. cervina at species level is relatively high. Conversely, low genetic diversity was detected at population level [90].

In a study with 13 populations of Perovskia abrotanoides, nine selected ISSR primers produced 119 discernible bands, with $80.7 \%$ polymorphism. The genetic similarity values between populations ranged from 0.07 to 0.79 , indicating a high level of genetic variation. The applicability of ISSR markers to characterize the populations of Perovskia abrotanoides was compared, being the first attempt to use molecular markers to investigate the genetic relationships of $P$. abrotanoides populations. The information generated can be useful to improve the agro-morphological and phytochemical traits of this species [91].

In a study aiming at the fast and precise identification of Mentha L. species, ISSR markers were used to estimate the genome size, determine the inter and intraspecific variation within the genus Mentha, and describe the relationships between genotypes. Thirty-seven ISSR primers were used, which resulted in the amplification of 333 loci and $100 \%$ polymorphism. The number of bands varied from 13 to 24 . Moreover, the UPGMA method divided the species into seven clusters. These markers are recommended for the identification of Mentha L. species/cultivars during reproduction, conservation, and germplasm collection [92].

The characterization of the genetic diversity of a native population of Eplingiella fruticosa of the state of Sergipe, Brazil, using ISSR molecular markers revealed an intermediate genetic diversity. The 100 plants analyzed, collected in 11 municipalities of the state of Sergipe, were evaluated by eight ISSR primers, resulting in 72 informative bands. The clustering analysis by the UPGMA method resulted in three clusters. The smallest genetic distance occurred between plants EPF94 and EPF96 (0.250), and the greatest distance was detected between the plants EPF50 and EPF96 (0.9778). The polymorphic information content (0.253) was considered moderately informative. These results can support the conservation and use of the genetic resources of Eplingiella fruticosa [93].

\section{AFLP (Amplified Fragment Length Polymorphism)}

The Amplified Fragment Length Polymorphism (AFLP) markers are based on the selective PCR amplification of total 
genomic DNA fragments generated by cleavage, using restriction enzymes. The methodology combines specificity, resolution, and sampling power by the restriction enzyme digestion, being fast and practical in detecting polymorphisms. This technique has been widely used for fingerprinting and genetic mapping purposes, especially in cultivated plant species that have low DNA polymorphism [94-95].

AFLP analysis consists of four steps: in the first, the genomic DNA of the individual is cleaved by two restriction enzymes; in the second, specific adapters are attached to the ends of the genomic fragments generated by the cleavage; in the third, a fraction of the fragments generated is amplified selectively via PCR, using specific primers designed to recognize sequences in the adapters; and in the fourth, the subpopulation of amplified fragments is separated in high-resolution gel $[25,96]$.

One of the advantages of this technique is the detection of high indices of polymorphisms per reaction; also, no prior knowledge of the DNA sequence data is required to construct the primers [97]. The disadvantage is the lesser information content per locus due to the dominant nature of these markers, i.e., they do not differentiate homozygote from heterozygote genotypes [25].

The diversity and genetic structure of 14 wild populations of Lippia graveolens located in four distinct regions of Southeastern Mexico were analyzed using AFLP markers. Some parameters, such as the genetic diversity of Nei $\left(\mathrm{H}_{\mathrm{j}}\right)$, cluster analysis, and Bayesian analysis were estimated. The authors observed that thymol had the highest genetic diversity in the chemotypic analysis. The Bayesian analysis revealed a low but significant differentiation between chemotypes. As for the genetic variability, populations dominated by individuals of the thymol chemotype presented higher diversity $\left(\mathrm{H}_{\mathrm{j}}=0.31-0.25\right)$ than populations with exclusively sesquiterpene chemotype $\left(\mathrm{H}_{\mathrm{j}}=0.058\right)$. These results confirm that the genetic variability influences the chemical profiles, as well as environmental and biotic factors, which play an essential role in determining the structure and the chemotype of this species [98].

The kinship degree and the genetic variation distribution in Tectona grandis (popularly known as teak) cultivated in Côte d'Ivoire, were analyzed using AFLP markers. This species is crucial in afforestation and is exploited uncontrollably due to the quality of its physical properties. In this work, the AFLP markers demonstrated a clear differentiation between the populations introduced in Côte d'Ivoire, showing that they came from North India [99].

The species Lippia origanoides is economically significant for the region of the Chicamocha river basin, in Northeastern Colombia, due to the quality of its essential oils and to the fact that its distribution is restricted to the few semi-arid areas of Northern South America. By using AFLP markers and 173 individuals sampled from four populations, a relatively high genetic diversity was detected within populations $(\mathrm{Ht}=0,32$; I $=0,48$ ). Nevertheless, in populations located at higher altitudes, diversity was significantly lower, probably due to more extreme environmental conditions. Therefore, the differences in altitude between the Chicamocha river basins seem to be relevant in determining the genetic structure of this species [100].

The chemical characterization of the essential oil components [by gas chromatography/mass spectrometry (GC/MS)] and the genetic characterization of 27 cultivars of Ocimum basilicum using AFLP, revealed differences between the morphotypes evaluated. The GC/MS analysis identified 87 volatiles and five chemotypes. The authors stated that a relationship between a genetic profile, chemical composition, and morphology characterizes a fundamental step to future breeding programs and the in the cultivation of this species [101].

By the AFLP technique, the genetic diversity between ten accessions of Mentha (Lamiaceae) represented seven taxa and one interspecific hybrid. Six primer combinations were used, generating 2049 bands, of which 1,779 were polymorphic, 29 were monomorphic, and 141 were unique. The authors estimated the similarity indices and performed the cluster analysis to construct a dendrogram, which revealed the kinship degree of the hybrid "Neerkalka" (CIMAP/C63) with one of the accessions (M. arvensis) [102].

Using this same species and technique, the genetic diversity and the genetic relationships between Mentha accessions was evaluated, aiming at determining the taxonomy of several interspecific hybrids. Therefore, 62 mint individuals representing five species and three hybrids were evaluated. An average of 40 AFLP markers was generated, and the percentage of polymorphism ranged from $50 \%$ to $60 \%$ among all accessions studied. Although the number of mint accessions used in this study represents only a small sample of the mint germplasm available, the AFLP analysis has the potential to be used with a larger number of accessions [103].

The characterization of essential oil variability and the general congruence between the chemotype and the genetic clustering of wild and cultivated populations of Salvia desoleana using AFLP markers suggested the existence of a genetic influence on the chemical composition of its essential oil. This information will help the conservation and the improvement of the commercial value of S. desoleana [104].

In Teucrium arduini, the AFLP analysis separated the populations investigated into two clusters, based mainly on the geographic distance. The Mantel test revealed that the correlation observed between the morphological traits and AFLP was stronger than that detected between the essential oil profile and AFLP. In addition, the test presented a stronger association between the essential oil profile and geographic position than between the morphological traits and geographic position. This study contributes to the knowledge of the little-investigated flora of the Western Balkan Peninsula [105].

AFLP markers were used to evaluate the genetic variability in populations of Phyla scaberrima by AFLP markers. Three 
combinations of AFLP primers resulted in 997 markers in a sample of 131 individuals from five populations (two populations from Mexico and three from Colombia). The low levels of genetic diversity detected in these populations showed an urgent management strategy must be developed to recover the genetic variability of the populations from Mexico and Colombia [106].

\section{Conclusion}

Molecular markers have contributed significantly to the generation of knowledge on bioactive species of the families Verbenaceae and Lamiaceae. Several other studies have also applied the ISSR and SSR markers. Such studies help understand the population genetic structure of poorly studied species and assist the development of conservation strategies and the future use of these genetic resources in breeding programs.

\section{Acknowledgment}

The authors thank CNPq, FAPITEC/SE, CAPES, and FINEP for their financial support for research in bioactive plants of Sergipe, Brazil.

\section{References}

1. Gallacher DJ (1997) Optimised descriptors recommended for Australian sugarcane germplasm (Saccharum spp. hybrid). Australian journal of agricultural research 48: 775-779.

2. Giancola S, Poltri SM, Lacaze P, Hopp HE (2002) Feasibility of integration of molecular markers and morphological descriptors in a real case study of a plant variety protection system for soybean. Euphytica 127: 95-113.

3. Benecke M (1997) DNA typing in forensic medicine and in crimina investigations: a curren survey. Naturwissenschaften 84(5): 181-188.

4. Borém A, Caixeta ET (2006) Marcadores moleculares. Universidade Federal de Viçosa, Viçosa, Minas Gerais, Brasil, pp. 9-66.

5. Ozkan M (2008) Glandular and eglandular hairs of Salvia recognita Fisch. and Mey. (Lamiaceae) in Turkey. Bangladesh Journal of Botany 37(1): 93-95.

6. Judd WS, Campbell CS, Kellogg EA, Stevens PF (1999) Plant systematics: a phylogenetic approach. Sunderland: Sinauer Associates.

7. Brandão AD, Viccini LF, Salimena FRG, Vanzela ALL, Recco-Pimentel (2007) Cytogenetic characterization of Lippia alba and Lantana camara (Verbenaceae) from Brazil. J Plant Res 120(2): 317-321.

8. Souza VC, Lorenzi H (2005) Verbenaceae, Botânica sistemática. Instituto Plantarum de Estudos da Flora, Nova Odessa, Brazil, pp. 529532

9. Pascual ME, Slowing K, Carretero E, Mata DS, Villar A (2001) Lippia: traditional uses, chemistry and pharmacology: a review. J Ethnopharmacol 76(3): 201-214.

10. Viccini LF, Pierre PMO, Praça MM, Costa DCS, Romanel EC, et al. (2006) Chromosome numbers in genus Lippia (Verbenaceae). Plant Systematic and Evolution 256(1-4): 171-178.

11. Sena-Filho JG, Xavier HS, Barbosa JM, Duringer JM (2010) A chemical marker proposal for the lantana genus: composition of the essential oils from the leaves of Lantana radula and Lantana canescens. Natural Product Commun 5(4): 635-640.

12. Rimpler H, Sauerbier AH (1986) Iridoid glucosides as taxonomic markers in the genera Lantana, Lippia, Aloysia and Phyla. Biocheminstry Systematic Ecology 14(3): 307-310.
13. Cavalcanti SCH, Niculau ES, Blank AF, Câmara CAG, Araújo IN, et al. (2010) Composition and acaricidal activity of Lippia sidoides essential oil against two-spotted spider mite (Tetranychus urticae Koch). Bioresour Technol 101(2): 829-832.

14. Mendes SS, Bomfim RR, Jesus HC, Alves PB, Blank AF, et al. (2010) Evaluation of the analgesic and anti-inflammatory effects of the essential oil of Lippia gracilis leaves. J Ethnopharmacol 129(3): 391397.

15. Viccini LF, Costa DCS, Machado MA, Campos AL (2004) Genetic diversity among nine species of Lippia (Verbenaceae) based on RAPD Markers. Plant Systematic Evolution 246(1-2): 1-8.

16. Lorenzi H, Matos FJA (2002) Plantas medicinais no Brasil: nativas e exóticas cultivadas. Instituto Plantarum, Nova Odessa, Brazil.

17. Harley RM (2012) Checklist and key of genera and species of the Lamiaceae of the Brazilian Amazon. Rodriguésia 63(1): 129-144.

18. Harley RM, Atkins S, Budantsev A, Cantino PH, Conn B, et al. (2004) Labiatae. In: Kadereit JW (ed.), The families and genera of vascular plants. Kubitzki, ( $7^{\text {th }}$ edn), pp. 167-275.

19. Harley RM, França F, Santos EP, Santos JS (2010) Lamiaceae. In: Catálogo de plantas e fungos do Brasil, Jardim Botânico do Rio de Janeiro 2: 1130-1146.

20. Alonso JLF, Díaz OR (2006) Libro rojo de plantas de Colombia. Instituto de Ciencias Naturales - Universidade Nacional de, Bogotá, Colômbia.

21. Sarac N, Ugur A (2007) Antimicrobial activities and usage in folkloric medicine of some Lamiaceae species growing in Mugla, Turkey. Eur Asian Journal of BioScience 1: 28-34.

22. Hendawy SF, Ezz El-Din AA, Aziz EE, Omer EA (2010) Productivity and oil quality of Thymus vulgaris $\mathrm{L}$. under organic fertilization conditions. Journal of Applied Science 3: 203-216.

23. Naguib NYM (2011) Organic Vs Chemical Fertilization of Medicinal Plants: A Concise Review of Researches. Advances in Environmental Biology 5: 394-400.

24. Botrel MCG, Carvalho D (2004) Variabilidade isoenzimática em populações naturais de jacarandá paulista (Machaerium villosum Vog.) Revista Brasileira de Botânica 27(4): 621-627.

25. Ferreira ME, Grattapaglia D (1998) Introdução ao uso de marcadores moleculares em análise genética. ( $3^{\text {rd }}$ edn), Embrapa-Cenargen, Brasília, pp. 220.

26. Pinto SIC, Souza AM, Carvalho D (1978) Variabilidade genética por isoenzimas em populações de Copaifera langsdorffii em dois fragmentos de mata ciliar. Scientia Forestalis 40-48.

27. Brown AH (1978) Isozymes, plant population genetic structure and genetic conservation. Theor Appl Genet 52(4): 145-157.

28. Jaaska V (1980) Electrophoretic survey of seedling esterases in wheats in relation to their phylogeny. Theor Appl Genet 56(6): 273-284.

29. Figueiredo-Ribeiro RCL, Almeida VP (1986) Análise enzimática equimiotaxonomia de duas variedades de Ocimum nudicaule Benth. Revista Brasileira de Botânica 9(1): 75-80.

30. Oliveira F, Carvalho D, Rosado SCS (2002) Taxa de cruzamento e sistema reprodutivo de uma população natural de Copaifera langsdorffii Desf na região de Lavras (MG) por meio de isoenzimas. Revista Brasileira de Botânica 25(3): 331-338

31. Dostálek T, Münzbergová Z, Plačková I (2009) Genetic diversity and its effect on fitness in an endangered plant species, Dracocephalum austriacum L. Conservation Genetics 11(3): 773-783.

32. Ali IBEH, Guetat A, Boussaid M (2012) Genetic diversity and structure of wild Tunisian Thymuscapitatus (L.) Hoffm. et Link. (Lamiaceae) 
assessed using isozyme markers. African Journal of Ecology 50(2): 140-151.

33. Fadhel NB, Boussaïd M (2004) Genetic diversity in wild Tunisian populations of Mentha pulegium L. (Lamiaceae). Genetic Resources and Crop Evolution 51(3): 309-321.

34. Zaouali Y, Boussaid M (2008) Isozyme markers and volatiles in Tunisian Rosmarinus officinalis L. (Lamiaceae): A comparative analysis of population structure. Biochemical Systematics and Ecology 36(1): 11-21.

35. Boulila A, Béjaoui A, Messaoud C, Boussaid M (2008) Variation of volatiles in Tunisian populations of Teucrium polium L. (Lamiaceae). Chemistry and biodiversity 5(7): 1389-1400.

36. Botstein D, White LR, Skolnick M, Davis RW (1980) Construction of a genetic link a gemap in manusing restriction fragment length polymorphisms. Am J Hum Genet 32(3): 314-331.

37. Smith OS, Smith JS, Bowen SL, Tenborg RA, Wall SJ (1990) Similarities among a group of elite maize in breds as measured by pedigree, F1 grain yield, grain yield, heterosis, and RFLPs. Theor Appl Genet 80(6): 833-840.

38. O'donoughue LS, Souza E, Tanksley SD, Sorrells ME (1994) Relationships among North American Oat Cultivars Based on Restriction Fragment Length Polymorphisms. Crop Science 34(5): 1251-1258.

39. Parani M, Lakshmi M, Senthilkumar P, Ram N, Parida A (1998) Molecular phylogeny of mangroves $\mathrm{V}$. Analysis of genome relationships in mangrove species using RAPD and RFLP markers. Theoretical and Applied Genetics 97(4): 617-625.

40. Bertea BCM, Luciano P, Bossi S, Leoni F, Baiocchi C, et al. (2006) PCR and PCR-RFLP of the 5S-rRNA-NTS region and salvinorin A analyses for the rapid and unequivocal determination of. Phytochemistry 67(4): 371-378.

41. Karaca M, Ince AG, Ay ST, Turgut K, Onus AN (2008) PCR-RFLP and DAMD-PCR genotyping for Salvia species. Journal Science Food Agriculture 88(14): 2508-2516.

42. Sousa VA, Filho ANK, Martins EG, Shimizu JY, Albertin F (2018) gene diversity in Grevillea populations introduced in Brazil and its implication on management of genetic resources. Revista Árvore 42(2): e420205.

43. Condit R, Hubbell SP (1991) Abundance and DNA frequence of 2-base repeat regions in tropical tree genomes. Genome 34(1): 66-71.

44. Lieckfeldt E, Meyer W, Borner T (1993) Rapid identification and differentiation of yeast by DNA and PCR fingerprinting. JBasic Microbiol 33(6): 413-426.

45. Meyer W, Lieckfeldt E, Kuhls K, Freedman EZ, Borner T, et al. (1993) DNA and PCR fingerprinting in fungi. In: Pena SDJ, Chakraborty R, Epplen JT, Jeffreys AJ (eds.), DNA Fingerprinting: State of the Science. Birkhauser, Verlag, Switzerland, pp. 311-320

46. Hamada H, Petrino MG, Kakunaga T (1982) A novel repeated element with ZDNA forming potential is widely found in evolutionarily diverse eukaryotic genomes. Proc Natl Acad Sci USA 79(21): 6465-6469.

47. Tautz D, Renz M (1984) Simple sequences are ubiquitous repetitive components of eukaryotic genomes. Nucleic Acids Res 12(10): 4127 4138.

48. Morgante M, Olivieri AM (1993) PCR-amplified microssatellites as markers in plant genetics. Plant J 3(1): 175-182.

49. Milach SCK (1998) Marcadores moleculares em plantas. UFRGS, Porto Alegre, Brazil, pp. 29-40.

50. Matioli SR (2001) Biologia Molecular e Evolução. Holos, pp. 153-161.

51. Tautz D (1989) Hypervariability of simple sequences as a general source for polymorphic DNA markers. Nucleic Acids Res 17(16): 64636471.
52. Blair MW, Pedraza F, Buendia HF, Gaitan-Solis E, Beebe SE, et al. (2003) Development of a genome-wide anchored microsatellite map for common bean (Phaseolus vulgaris L.). Theor Appl Genet 107(8): 13621374.

53. Song QJ, Marek LF, Shoemaker RC, Lark KG, Concibido VC, et al. (2004) A new integrated genetic linkage map of the soybean. Theor Appl Genet 109(1): 122-128.

54. Borém A, Caixeta ET (2009) Marcadores Moleculares. (2 ${ }^{\text {nd }}$ edn), Viçosa, Minas Gerais, Brasil, pp. 532.

55. Faleiro FG, Faleiro ASG, Cordeiro MCR, Karia CT (2003) Metodologia para operacionalizar a extração de DNA de espécies nativas do cerrado. Planaltina: Embrapa Cerrados, pp. 6.

56. Faleiro FG (2007) Marcadores genético-moleculares aplicados aos programas de conservação e uso de recursos genéticos. Planaltina, DF: Embrapa Cerrados, pp. 102.

57. Mizusawa L, Kaneko S, Hasegawa M, Isagi Y (2011) Development of nuclear SSRs for the insular shrub Clerodendrum izuinsulare (Verbenaceae) and the widespread C. trichotomu. American Journal of Botany, pp. 333-336.

58. Thode VA, Backes A, Mader G, Kriedt R, Bonatto SL, et al. (2013). Development of Microsatellites for Verbenoxylum reitzii (Verbenaceae), a Tree Endemic to the Brazilian Atlantic Forest. Appl Plant Sci 1(8).

59. Sandes SS, Pinheiro JB, Zucchi MI, Monteiro M, Arrigoni-Blank MF, et al. (2013) Development and characterization of microsatellite primers in Pogostemon cablin (Lamiaceae). Genet Mol Res 12(3): 2837-2840.

60. Radosavljević I, Satovic Z, Jakse J, Javornik B, Greguraš D, et al. (2012) Development of New Microsatellite Markers for Salvia officinalis L. and its potential use in conservation-genetic studies of narrow endemic Salvia brachyodon Vandas. Int J Mol Sci 13(9): 12082-12093.

61. Bonafede M, Marsal V, Arteaga M (2014) Diversity distribution analysis in Minthostachys verticillata Epling (Griseb) (Lamiaceae) (peperina) populations by EST-SSR markers. Journal of Biodiversity and Environmental Sciences (JBES) 5(6): 190-199.

62. Aboukhalida K, Machon N, Lambourdiered J, Abdelkrimd J, Bakhaa M, et al. (2017) Analysis of genetic diversity and population structure of the endangered Origanum compactum from Morocco, using SSR markers: Implication for Conservation. Biological Conservation 212(A): 172182.

63. Segarra-Moragues JG, Marco YC, Castellanos MC, Molina MJ, GarcíaFayos P (2016) Ecological and historical determinants of population genetic structure and diversity in the Mediterranean shrub Rosmarinus officinalis (Lamiaceae). Botanical Journal of the Linnean Society 180(1): 50-63.

64. Rocha DS, Santos CP, Bajay MM, Campos JB, Blank AF, et al. (2015) Development of a novel set of microsatellite markers for Lippia alba (Verbenaceae). Genet Mol Res 14(1): 971-974.

65. Chaves CL, Ruas EA, Ruas CF, Delfini J, Bejatto NC, et al. (2014) Isolation and characterization of simple sequence repeat markers for the herbaceous species Phyla scaberrima (Verbenaceae). Genet Mol Res 13(3): 7864-7868.

66. Lacerda DR, Acedo MDP, Lemos-Filho JP, Lovato MB (2002) A técnica de RAPD: uma ferramenta molecular em estudos de conservação de plantas. Lundiana 3(2): 87-92.

67. Tingey SV, Rafalski JA, Williams JGK (1993) Application of RAPD Technology to Plant Breeding. In: Neff M (Ed.), ASHS Publishers, Minnesota, USA, pp. 3-8.

68. Williams JGK, Kubelik AR, Livak KJ, Rafalskij A, Tingey SV (1990) DNA polymorphims amplified by arbitrary primers are useful as genetic markers. Nucleic Acids Res 18(22): 6531-6535.

69. Michelmore RW, Paran I, Kesseli RY (1991) Identification of markers linked to disease resistance genes by bulked segregant analysis: a rapid 
method to detect markers in specific genomic regions using segregating populations. Proc Natl Acad Sci USA 88(1): 9828-9832.

70. Delourme R, Bouchereau A, Hubert N, Renard M, Landry BS (1994) Identification of RAPD markers linked to a fertility restorer gene for the Ogura radish cytoplasmic male sterility of rapeseed (Brassica napus L.). Theor Appl Genet 88(6-7): 741-748.

71. Tanhuanpaa PK, Vikki JP, Vikki HJ (1996) Mapping of QTL for oleic acid concentration in spring turnip rape (Brassica rapa ssp oleifera). Theor Appl Genet 92(8): 952-956.

72. Sarwat M, Nabi GDS, Srivastava OS (2011) Molecular markers in medicinal plant biotechnology: past and present. Crit Rev Biotechnol 32(1): 1-19.

73. Lacerda DR, Acedo MDP, Lemos-Filho JP, Lovato MB (2002) A técnica de RAPD: uma ferramenta molecular em estudos de conservação de plantas. Lundiana 3(2): 87-92.

74. Fritsch P, Rieseberg LH (1996) The use of Random Amplified Polymorphic DNA (RAPD) in conservation genetics. In: Smith TB, Wayne RK. Molecular genetic approaches in conservation. Oxford University Press, New York, USA, pp. 54-73.

75. Zhang GF, Guan JM, Lai XP, Lin J, Liu JM, et al. (2012) RAPD fingerprint construction and genetic similarity of Mesona chinensis (Lamiaceae) in China. Genet Mol Res 11(4): 3649-3657.

76. Samantaray S, Bishoyi AK, Maiti S (2013) Regeneracion de plantas a partir de cultivos de callos de Vitex trifolia (Lamiales: Lamiaceae): una planta medicinal potencial. Revista de Biologia Tropical 61(3): 1083.

77. Pierre PMO, Souza SM, Davide LC, Machado MA, Viccini LF (2011) Karyotype analysis, DNA content and molecular screening in Lippia alba (Verbenaceae). Academia Brasileira de Ciências 83(3).

78. Ruzicka J, Lukas B, Merza L, Göhler I, Abel G, et al. (2009) Identification of Verbena officinalis Based on ITS Sequence Analysis and RAPDDerived Molecular Markers. Planta Med 75(11): 1271-1276.

79. Chowdhury T, Mandal A, Roy SC, Sarker DD (2017) Diversity of the genus Ocimum (Lamiaceae) through morpho-molecular (RAPD) and chemical (GC-MS) analysis. Journal of Genetic Engineering and Biotechnology 15(1): 275-286.

80. Zietkiewicz E, Rafalski A, Labuda D (1994) Genome fingerprinting by simple sequence repeat (SSR) anchored polymerase chain reaction amplification. Genomics 20(2): 176-183.

81. Souframanien J, Gopalakrishna T (2004) A comparative analysis of genetic diversity in blackgram genotypes using RAPD and ISSR markers. Theor App Genet 109(8): 1687-1693.

82. Reddy MP, Sarla N, Siddiq EA (2002) Inter simple sequence repeat (ISSR) polymorphism and its application in plant breeding. Euphytica 128(1): 9-17.

83. Goulão L, Oliveira C (2002) Molecular characterization of cultivars of apple (Malus x domestica Borkh.) using microsatellite (SSR and ISSR) markers. Euphytica 122: 81-89.

84. González A, Coulson M, Brettell R (2002) Development of DNA markers (ISSRs) in mango. Acta Horticulturae 575: 139-143.

85. Culley TM, Wolfe AD (2001) Population genetic structure of the cleistogamous plant species Viola pubescens, as indicated by isozyme and ISSR molecular markers. Heredity (Edinb) 86(Pt 5): 545-556.

86. Tsumura Y, Ohba K, Strauss SH (1996) Diversity and inheritance of inter-simple sequence repeat polymorphisms in Douglas-fir (Pseudotsuga menziesii) and sugi (Cryptomeria japonica). Theoretical and Applied Genetics 92(1): 40-45.

87. Sena-Filho JG, Rabbani ARC, Silva TRS, Silva AVCda, Souza IA, et al. (2012) Chemical and molecular characterization of fifteen species from the Lantana (Verbenaceae) genus. Biochemical Systematics and Ecology 45: 130-137.

88. Manica-Cattani MF, Zacaria J, Pauletti G, Atti-Serafini L, Echeverrigaray S (2009) Genetic variation among South Brazilian accessions of Lippia alba Mill. (Verbenaceae) detected by ISSR and RAPD markers. Braz J Biol 69(2): 375-380.

89. Kameli M, Hejazi SMH, Ebadi M (2013) Assessment of genetic diversity on populations of three Satureja species in Iran using ISSR markers. Annals of Biological Research 4(3): 64-72.

90. Rodrigues L, Póvoa O, Berg CVD, Figueiredo AC, Moldão M, et al. (2013) Genetic diversity in Mentha cervina based on morphological traits, essential oils profile and ISSRs markers. Biochemical Systematics and Ecology 51: 50-59.

91. Pourhosseini SH, Hadian J, Sonboli A, Ebrahimi SN, Mirjalili MH (2018) Genetic and chemical diversity in Perovskia abrotanoides KAR. (Lamiaceae) Populations Based on ISSRs Markers and Essential Oils Profile. Chemical Biodivers 15(3): e1700508.

92. Jedrzejczyk I, Rewers M (2018) Genome size and ISSR markers for Mentha L. (Lamiaceae) genetic diversity assessment and species identification. Industrial Crops and Products 120: 171-179.

93. Silva DC, Diniz LEC, Blank AF, Nizio DAC, Pinto JAO, et al. (2017) Assessment of genetic diversity of a native population of Eplingiella fruticosa: a plant with therapeutic potential. Genet Mol Res 16(3).

94. Vos P, Hogers R, Bleeker M, Reijans M, Lee TV de, et al. (1995) AFLP: a new technique for DNA fingerprinting. Nucleic Acids Res 23(21): 44074414

95. Liu BH (1968) Statistical genomics: linkage, mapping and QTL analysis. CRC Press, New York, USA, pp. 611.

96. Ramalho MAP, Santos JB, Pinto CABP (2000) Genética na agropecuária. UFLA, Lavras, Minas Gerais, Brasil, pp. 472.

97. Faleiro FG, Lopes UV, Yamada MM, Pires JL, Bahia RCS, et al. (2001) Caracterização de variedades clonais de Theobroma cacao L. com base em marcadores RAPD, AFLP e microssatélites. Agrotrópica 13(2): 7986.

98. Martinez-Natarén DA, Parra-Tabla V, Ferrer-Ortega MM, Calvo-Irabién LM (2014) Genetic diversity and genetic structure in wild populations of Mexican oregano (Lippia graveolens HBK) and its relationship with the chemical composition of the essential oil. Plant Systematics and Evolution 300(3): 535-547.

99. Fofana IJ, Diarrassouba N, Silue S, Koffi KK, Adou K (2013) Origin of african teak (Tectona grandis) provenances in Côte d'ivoire using AFLP markers. Elite Research Journal of Biotechnology and Microbiology 1(1): 1-8.

100. Vega-Vela NE, Sánchez MI (2012) Genetic structure along an altitudinal gradient in Lippia origanoides, a promising aromatic plant species restricted to semiarid areas in northern South America. Ecol Evol 2(11): 2669-2681.

101. Liber Z, Carovic-Stanko K, Politeo O, Strikic F, Kolak I, et al. (2011) Chemical Characterization and Genetic Relationships among Ocimum basilicum L. Cultivars. Chem Biodivers 8(11): 1978-1989.

102. Shasany AK, Shukla A, Gupta S, Rajkumar S, Khanuja SPS (2005) AFLP analysis for genetic relationships among Mentha species. Plant Genetic Resources 144: 14-19.

103. Gobert V, Moja S, Colson S, Taberlet P (2012) Hybridization in the section Mentha (Lamiaceae) inferred from AFLP markers. Am J Bot 89(12): 2017-2023.

104. Rapposelli E, Melito S, Barmina GG, Foddai M, Azara E, et al. (2015) AFLP fingerprinting and essential oil profiling of cultivated and wild populations of Sardinian Salvia desoleana. Genetic Research Crop Evolution 62(6): 959-970. 
105. Kremer D, Bolaric S, Ballian D, Bogunic F, Steševic D, et al. (2015) Morphological, genetic and phytochemical variation of the endemic Teucrium arduini L. (Lamiaceae). Phytochemistry 116: 111-119.
106. Androcioli LG, Ruas EA, Rodrigues LA, Ruas CF, Perilla HER, et al (2015) Population genetic structure in Phyla scaberrima from Mexico and Colombia assessed by AFLP markers and implications for conservation. Genet Mol Res 14(4): 15697-15704.

\section{Your next submission with Juniper Publishers will reach you the below assets}

- Quality Editorial service

- Swift Peer Review

- Reprints availability

- E-prints Service

- Manuscript Podcast for convenient understanding

- Global attainment for your research

- Manuscript accessibility in different formats

( Pdf, E-pub, Full Text, Audio)

- Unceasing customer service

Track the below URL for one-step submission https://juniperpublishers.com/online-submission.php 